\title{
RESOURCE-SEEKING AGGLOMERATION: A STUDY OF MARKET ENTRY IN THE LODGING INDUSTRY
}

\author{
Arturs Kalnins \\ University of Southern California \\ Wilbur Chung \\ University of Pennsylvania
}

We analyze whether firms prefer collocating with incumbent firms when choosing among markets to enter, highlighting the role of resource-seeking as a motivation for collocation. We propose that entrants will locate near others possessing resources that can spill over, but will avoid locations where existing firms will exploit spillovers without contributing. To test these propositions, we analyze the location decisions of 570 new hotels in Texas between 1992 and 2000. We find that hotels are attracted to markets with branded upscale hotels. Further, we find that owners of upscale hotels avoid markets with hotels without similar resources.

In the last decade, extensive research has analyzed the firm's quest for resources that will yield sustainable competitive advantages (see, for example, Barney and Arikan, 2001, for an extensive review). Finding such resources is not a simple task. Dierickx and Cool (1989) argued that resources capable of serving as a basis for sustainable advantage are often firm-specific and take time to accumulate. They cannot simply be bought, those authors argued, because the seller would have already largely appropriated the value of the advantage in the selling price. In addition to developing advantages internally, the literature on alliances has indicated that voluntary interfirm linkages may be another way to acquire resources (e.g., Rao and Ruekert, 1994; Dyer and Singh, 1998). Yet, Ahuja (2000) argued that seeking alliances may not be a valuable strategy for low-resource firms to gain resources, because few partners will emerge for those who have no resources of their own to contribute to a cooperative arrangement.

Some production-enhancing resources, though, such as manufacturing technologies or a welltrained workforce, can involuntarily spill over to geographically proximate firms (Almeida and Kogut, 1999; Jaffe, Trajtenberg, and Henderson, 1993). Further, Shaver and Flyer (2000) argued that manufacturing firms contribute to and benefit very differently from spillovers based on the resources they themselves possess. Meanwhile, Fischer and Harrington (1996) presented theory that retail and service firms can benefit from heightened demand caused by agglomeration even with no explicit spillovers. In this paper, we incorporate the idea of spillovers into the demand- heightening agglomeration theory relevant to retail and service firms, arguing that low-resource firms will locate proximately to others, hoping that resources will spill over to them. High-resource firms should also locate in the vicinity of some other firms, but only when those incumbents also possess resources.

The paper proceeds as follows. In the next section, we present a literature review of prior agglomeration research. In the theory development section, we derive hypotheses for how firm heterogeneity and market heterogeneity interact to influence patterns of market entry. We then 
describe our analysis of the location decisions made by existing hotel owners for 570 new hotels in Texas between 1992 and 1999. We argue that the hotel industry is particularly appropriate for this study, because the enticement of agglomeration benefits and resource spillovers likely plays a role in location decisions. A methods section is followed by the description of data and variables, the empirical results, a discussion and conclusion.

\section{LITERATURE REVIEW: BENEFITS FROM AGGLOMERATION}

Marshall (1920) argued that agglomeration economies exist in many industries, both in manufacturing as well as in the retail and service sector. In the manufacturing case, the benefits of agglomeration are in production; multiple firms in the same area promote spillovers of technical knowledge and the development of a skilled local workforce. Consistent with this argument, Carlton (1983) and Head, Ries, and Swenson (1995) found that high levels of similar industry activity increase the probability of a firm locating a plant in that area.

Agglomeration among retail or service firms can heighten demand by attracting more customers than the sum of those that the agglomerating firms would attract individually. The concept of spillovers is not required for this basic argument. Heightened demand occurs because customers minimize search costs by visiting a location where many firms are present. Fischer and Harrington (1996) demonstrated in a theoretical model with products requiring visual inspection that the more heterogeneous the product, the greater the collocation of firms that will result. While the firms in Fischer and Harrington's model are heterogeneous in terms of their product attributes, none are considered superior to others by all consumers. This assumption implies that all firms benefit from agglomeration equally and greater product heterogeneity necessarily increases agglomeration benefits. Further, the product heterogeneity between firms reduces competition (e.g., Tirole, 1988: 287-288) and may lead to some collocation even without considering agglomeration (Mazzeo, 2002). The combination of agglomeration benefits and reduced competition, however, makes collocation particularly appealing when between-firm product heterogeneity exists, and can explain the existence of 'auto malls' and 'food courts.'

The idea that collocating with other firms can provide agglomeration benefits seems to suggest that all firms should agglomerate. Yet, Barnett and Carroll (1987) argued and provided empirical support for 'mutualism,' in which the proximity of neighboring companies can be beneficial for a firm's survival but only when such neighbors have complementary demand. Consistent with this idea, Ingram and Baum (1997) found that, in time periods when more chain hotels existed in Manhattan, failure rates of unbranded hotels in Manhattan decreased, and vice versa. Similarly, Chung and Kalnins (2001) found that, when hotels affiliated with nationally known brands make up a larger proportion of a market, unaffiliated hotels in that market on average have higher revenues.

Shaver and Flyer (2000) illustrated an effect of firm heterogeneity distinct from mutualism as well as from the basic product heterogeneity necessary for demand-heightening agglomeration. They argued that the production-enhancing resources possessed by some firms may spill over and benefit those lacking such resources. Thus, to prevent resource spillovers, high-resource firms may not want to collocate with others. We extend this resource-seeking argument by recognizing that markets also differ based on the resources that firms in those markets possess and apply our argument to the case of demand-heightening agglomeration. 


\section{THEORY DEVELOPMENT: HYPOTHESES OF RESOURCEᄀSEEKING AGGLOMERATION}

We expect that, when the resource stocks of firms are heterogeneous, benefits of agglomeration will disproportionately accrue to low-resource firms due to resource spillovers. To illustrate this point below, we consider separately the entry decisions of a high-resource firm (Firm H) and a low-resource firm (Firm L). These firms can enter one of three types of markets: (1) markets where high-resource firms predominate (Market $\mathrm{H}$ ); (2) markets where low-resource firms predominate (Market L); and (3) a market with no other firms (Market O). Of course, firms' resources run along a continuum as do the resources present in markets; for parsimony in our development of expectations we restrict ourselves to the simplest case that effectively illustrates heterogeneity in both firms and markets.

First, we apply Fischer and Harrington's (1996) basic argument by considering where Firms H and $L$ would prefer to locate when there are only two location options: a market with their own type and an empty market (Market $\mathrm{O}$ ). Those authors demonstrate that agglomeration benefits will exceed competitive pressure if the products offered by firms are sufficiently heterogeneous and require personal inspection, but no firm necessarily possesses greater resource stocks than any other. Given these conditions, both Firm $\mathrm{H}$ and Firm $\mathrm{L}$ would prefer to locate in markets with others of their own type instead of avoiding competitive pressure by locating in empty Market $O$. The benefits of agglomeration in Fischer and Harrington's (1996) argument do not come from resource spillovers among firms, but rather they come from the attraction of additional customers drawn to the area because of the presence of many firms. These arguments are sufficient to yield two hypotheses:

Hypothesis 1: High counts of low-resource firms in a market will increase the probability that additional low-resource firms will choose that market relative to other markets.

Hypothesis 2: High counts of high-resource firms in a market will increase the probability that additional high-resource firms will choose that market relative to other markets.

Adding the concept of resource spillovers to this basic argument adds little insight to the two- market case described above because, while the products are heterogeneous, firms' resource stocks are assumed to be equal. If Firm $\mathrm{H}$ locates in Market $\mathrm{H}$, its resources may spill over to other high-resource firms, but Firm $\mathrm{H}$ may also gain by receiving spillovers from these other firms. Yet, as the resources of all firms in Market $\mathrm{H}$ are at a similar level, the contribution and gains of spillovers are likely to cancel out. The same would hold for Firm L in Market L.

The core argument of this paper is that by assuming heterogeneous resource stocks in addition to the possibility that these resources can spill over adds insight once the firms have three location options. Firm $\mathrm{L}$ now has the additional option of locating in Market $\mathrm{H}$, while Firm $\mathrm{H}$ can also locate in Market L. For Firm L, Market $\mathrm{H}$ provides some agglomeration benefits similar to those of Market $\mathrm{L}$, because the heterogeneity of demand-heightening resources also implies some product heterogeneity. Thus, Fischer and Harrington's (1996) argument predicts that Firm L prefers both Markets $\mathrm{H}$ and $\mathrm{L}$ to Market $\mathrm{O}$. But we argue that Firm $\mathrm{L}$ benefits the most by locating in Market $\mathrm{H}$. As Firm $\mathrm{L}$ has fewer resources than the firms in Market $\mathrm{H}$, it receives substantial spillovers from these high-resource incumbents. In addition, Firm L is not likely to suffer from competitive moves, such as pricing strategies, of the high-resource firms in Market $\mathrm{H}$. High-price firms such as those of Market $\mathrm{H}$ will often not find it profitable to respond to Firm L's lower price, because lowering their own prices to compete will reduce their profits more than would ceding some market share to Firm L (Brandenburger and Nalebuff, 1996).

Hypothesis 3a: High counts of high-resource firms in a market will increase the probability that low-resource firms will choose that market relative to other markets. 
Hypothesis $3 b$ : The effect predicted by Hypothesis $3 a$ will be stronger than that predicted by Hypothesis 1 above.

For Firm $\mathrm{H}$, the potential agglomeration gains in Market $\mathrm{L}$ associated with Fischer and Harrington's (1996) product heterogeneity argument are likely to be outweighed by losses for two reasons. First, the expected spillover of incumbents' resources to Firm $\mathrm{H}$ would be low since low-resource firms predominate in Market L. Second, low-resource firms may decide to rely on the spillovers of Firm H's demand-heightening resources to attract customers and thus invest even less in their own brands or reputations. Instead, they could lower prices to attract customers once Firm $\mathrm{H}$ has drawn those customers to the market. These two reasons suggest that Firm $\mathrm{H}$ will prefer Market $\mathrm{O}$ to Market $\mathrm{L}$. This logic yields the following hypothesis:

Hypothesis 4: High counts of low-resource firms in a market will decrease the probability that a high-resource firm will choose that market relative to other markets.

\section{ALTERNATIVE PROCESSES}

We have focused on the process of resource-seeking agglomeration, but other processes with distinct implications for location choice behavior are possible. We discuss five such processes and their implications. First, if the combination of product heterogeneity and the potential for resource spillovers are insufficient for agglomeration benefits to outweigh the effects of competition, then we should only observe competitive effects. Hotelling (1929), for example, hypothesized that firms in competitive markets should be observed avoiding locating proximately to others. Second, if most consumers would greatly prefer variety, in this case, a market where they could actively choose between the products of high- and low-resource firms, then mutualistic processes would dominate. New establishments should only be attracted to areas with high counts of establishments of the other type. Third, firms may benefit from a contrast effect in quality (e.g., Voss, Parasuraman, and Grewal, 1998). If so, then high- resource firms would prefer to locate next to firms that lack resources, to highlight their quality differences. Fourth, if the high-resource firms and low- resource firms served distinct segments of demand, agglomeration benefits and spillovers would be non-existent across types and there would be no need for high-resource firms to avoid the low- resource firm. New establishments should only be attracted to areas with high counts of firms of their own type. Finally, clustering in a market may be driven by an area-specific benefit that is independent of the presence or absence of other firms. Both high- and lowresource firms would be observed locating in such areas. While such alternate processes are certainly possible, our subsequent results are most consistent with the process of resource-seeking agglomeration.

\section{EMPIRICAL RESEARCH DESIGN}

We test our expectations using the U.S. hotel industry because demand-heightening agglomeration benefits, resource heterogeneity, and resource spillovers are likely to exist. As discussed above, demand-heightening agglomeration benefits result when products are heterogeneous and require personal inspection. Hotels satisfy this criterion; personal inspection may be required to observe quality or price. For example, a hotel may be poorly maintained, noisy as a result of being too close to traffic, or simply overpriced for the quality it offers. A customer is more likely to go where there are multiple hotels to compare quality and prices.

Substantial heterogeneity of demand-heightening resources exists in the hotel industry because some hotels are affiliated with nationally known branded chains, either via a franchising relationship or 
via ownership, while others are not. Relative to unbranded hotels, branded hotels will be able to attract more customers and charge premium prices because of resources built up through advertising and branding. Milgrom and Roberts (1986) demonstrated that firms wishing to credibly signal high quality will spend substantial amounts on advertising and set prices at a high enough level that allows them to recoup the advertising costs. Similarly, brands are a means of credibly committing to an appropriate quality level (Wernerfelt, 1988). If customers are provided lower quality than expected from a brand, they are likely to refuse to continue to support the brand, and the offending brand may even fare worse than low-quality brands (Rao and Ruekert, 1994). In the lodging industry, brands are particularly valuable as signals of quality because many travelers are not repeat customers (Ingram, 1996). Because advertising and branding entail fixed costs, hotels affiliated with nationally known branded chains can centralize these functions, allowing the many individual affiliates to enjoy the benefits (Caves and Murphy, 1976; Ingram and Baum, 1997). Therefore, branded hotels are most likely to enjoy the resources that attract customers to an area, and that can spill over to other firms.

We further argue that even among national brands the level of demand-heightening resources is heterogeneous. Therefore, we split brands into upscale and economy tiers. The upscale brands spend more time and effort to develop their resources. They must advertise more to maintain perceptions of quality. For example, in 1990, Holiday Inn spent over $\$ 19,000$ per hotel on advertising, while Howard Johnson's spent only $\$ 9000$, resulting in higher perceived quality for Holiday Inn (Cobb-Walgren, Ruble, and Donthu, 1995). Further, they must inspect more rigorously so that their hotels all meet the high standards of the brand.

Spillovers of demand-heightening resources are also likely to occur among hotels. Low-resource hotels, for example, can benefit when neighboring hotels with high resource stocks attract so much demand that it exceeds their capacity. The customers drawn to an area by the presence of an upscale hotel who encounter a 'no vacancy' sign have little choice but to stay at a proximate economy hotel. The trade press has frequently noted this type of spillover (Chung and Kalnins, 2001). We discovered two additional forms of spillover through informal interviews with managers of low- resource hotels. First, the presence of hotels with upscale brand names signals safety of an area. Second, the presence of an upscale hotel in an isolated market indicates that services such as a full-service restaurant and a gift shop are available at that location.

We summarize the implications for hotels of our resource-seeking hypotheses in Table 1. Branded upscale hotels will be drawn to markets with high counts of upscale incumbents (Hypothesis 2), while upscale hotels will avoid markets with high counts of branded economy and non-branded hotels (Hypothesis 4). Branded economy hotels and non-branded hotels will also be drawn primarily to markets with high counts of upscale hotels (Hypothesis 3a) and to areas with others like them (Hypothesis 1). Table 1 also shows how implications derived from the five alternative processes discussed above will differ from the resource-seeking hypotheses.

\section{DATA AND VARIABLES}

We test these hypotheses using data provided by the Texas Comptroller of Public Accounts. The data include entry and exit dates for all hotels operating in the State at some point between 1990 and 1999 , along with the owner's name and 'head-quarters' address, the hotel's name (including any brand affiliation), and the hotel's address. These data allow us to analyze the location decisions made by existing hotel owners for 570 new hotels in Texas between January 1992 and December 1999. As we use the counts of hotels in a zip code 2 years prior to each entry to test our hypotheses, we can only begin to analyze entries as of January 1992. 
Table 1. Comparison of resource-seeking hypotheses with those of alternative processes

Effect on likelihood of entry by:

\begin{tabular}{llll}
\hline & Resource-seeking & Competition & Mutualism \\
Unbranded hotels & Unbranded: $+(\mathrm{H} 1)$ & Unbranded: - & Unbranded: 0 or - \\
(low-resource firms) & Economy: $+(\mathrm{H} 1)$ & Economy: 0 or - & Economy: + \\
& Upscale: $++(\mathrm{H} 3 \mathrm{a})$ & Upscale: $0-$ or - & Upscale: + \\
$\begin{array}{l}\text { Branded economy hotels } \\
\text { (low-resource firms) }\end{array}$ & Unbranded: $+(\mathrm{H} 1)$ & Unbranded: 0 or - & Unbranded: + \\
& Economy: $+(\mathrm{H} 1)$ & Economy: - & Economy: 0 or - \\
Branded upscale hotels & Upscale: $++(\mathrm{H} 3 \mathrm{a})$ & Upscale: 0 or - & Upscale: + \\
(high-resource firms) & Unbranded: $-(\mathrm{H} 4)$ & Unbranded: 0 or - & Unbranded: + \\
& Economy: $-(\mathrm{H} 4)$ & Economy: 0 or - & Economy: + \\
& Upscale: $+(\mathrm{H} 2)$ & Upscale: - & Upscale: 0 or - \\
Unbranded hotels & Quality contrast & Segmented markets & Area-specific benefits \\
(low-resource firms) & Unbranded: 0 or - & Unbranded: + & Unbranded: + \\
& Economy: 0 or - & Economy: 0 & Economy: + \\
Branded economy hotels & Upscale: - & Upscale: 0 & Upscale: + \\
(low-resource firms) & Unbranded: 0 or - & Unbranded: 0 & Unbranded: + \\
& Economy: 0 or - & Economy: + & Economy: + \\
Branded upscale hotels & Upscale: - & Upscale: 0 & Upscale: + \\
(high-resource firms) & Unbranded: + & Unbranded: 0 & Unbranded: + \\
& Economy: + & Economy: 0 & Economy: + \\
& Upscale: 0 or - & Upscale: + & Upscale: + \\
\hline
\end{tabular}

+ indicates that the effect on probability of entry is positive $(++$ indicates higher in magnitude)

- indicates that the effect on probability of entry is negative

0 indicates no effect on probability of entry

Effect on market entry of high counts of:

The independent variables of theoretical interest are counts of hotels within a market. For our definition of a market, we use the five-digit zip code level as we believe it reasonably captures the set of hotels that will be directly compared by consumers. We count separately the upscale, economy, and unbranded hotels in each zip code 2 years before the opening of the new hotel. The upscale brands were split from the economy brands based on a brand's average AAA rating in Texas of 2.5 stars in the 1998 guidebook. Comfort Inn was the lowest ranked upscale brand, with 2.74 stars, while Ramada was the highest economy brand, with an average of 2.44 stars. This ranking is very consistent with Conlin's (2003) sector classification of all hotel brands operating in Texas.

We include several important control variables, because exogenous owner and market characteristics make some markets more appealing to hotel owners than others. First are three distance measures: the entering hotel's distance from its owner's headquarters, average distance from the owner's other existing hotels, and distance to the owner's nearest hotel that existed 2 years prior to the date the new hotel opens. We include these controls because new outlets are more likely to be located near to a firm's headquarters for ease of monitoring (Kalnins and Lafontaine, 2004) and near to the firm's existing outlets due to localized searching (Baum, Li, and Usher, 2000). These controls account for the constraining effects of distance, which might lead to a greater number of similar hotels in proximate locations. For branded entrants, we also control for whether other hotels of the same brand (but perhaps of a different owner, in the case of franchised brands) are present in a market because brands typically do not locate multiple hotels in the same market in order to avoid cannibalization (see, for example, Khanna and Ganot, 1995).

We include several market-level attributes to capture some area-specific benefits. Larger and wealthier markets are likely to attract more entrants for example. Therefore for each zip code we 
include residential population from the 1990 census, and the counts of all retail businesses and restaurants measured 2 years prior to the hotel's entry. Similarly, 1990 per capita income of each zip code is included to capture the effects of market wealth. Finally, to proxy for market growth, we include the net addition (entries less exits) of restaurants and retail outlets in the 2 years prior to entry. Without these variables, area-specific effects caused by a market's economic size, wealth, and growth may be misattributed to existing hotel counts in that market. Descriptive statistics for all variables are presented in Table 2.

\section{METHOD}

We use the conditional logit model to test our hypotheses (McFadden, 1974). Conditional logit has been used extensively for location choices made by firms considering a large set of possible geographical options (e.g., Head et al., 1995; Shaver and Flyer, 2000). Conditional logit is most appropriate for such an analysis because it allows the direct comparison of many discrete choices: the many markets possibly considered for each new hotel. Markets possessing high values of a variable that receives a positive coefficient have a higher probability of being chosen, exactly the format of our hypotheses. Negative coefficients indicate lower probabilities of being chosen.

\section{RESULTS}

In Table 3, we present results based on our sample split of 296 upscale, 161 economy, and 113 unbranded hotels. Table 3 presents two sets of three columns. Both sets of results reflect the entering firm's heterogeneity. The first set assumes homogeneous markets, while the second set accounts for market heterogeneity with counts of the three hotel types already in each market.

Looking at columns 1, 2, and 3, which ignore market heterogeneity, the upscale brands appear not to agglomerate, while the economy and unbranded hotels do agglomerate. The effect of number of hotels is significantly positive for unbranded hotels and marginally so for economy brands. This finding replicates, for the case of demand-heightening resources, Shaver and Flyer's (2000) main result regarding effects of spillovers on production-enhancing agglomeration: high- resource firms appear not to agglomerate, while low-resource firms do. Yet, our main interest is the agglomeration pattern once we introduce market heterogeneity.

The results in columns 4 through 6 of Table 3 incorporate the influence of market heterogeneity. In column 4, the significant and positive coefficient of the branded upscale hotel count variable indicates that upscale hotels are more likely to enter markets with high counts of others of the same type, supporting Hypothesis 2. Even though these hotels are best at attracting customers on their own, they still choose to agglomerate when the other hotels in the market are also upscale. Further, upscale hotels also specifically avoid locating in markets with high counts of economy hotels, supporting Hypothesis 4. While they also appear to avoid markets with high counts of unbranded hotels, the result is not statistically significantly different from zero.

In columns 5 and 6 we observe that for both the branded economy hotels and unbranded hotels the count of upscale hotels has a positive and significant impact on the probability of entering a given market. These results support Hypothesis 3a. These firms move into markets with upscale hotels in order to take advantage of spillovers because they possess fewer resources to attract customers on their own. Neither the branded economy nor the unbranded hotels are enticed by high counts of their own kind to enter markets, providing no support for Hypothesis 1. The lack of support for this hypothesis suggests that, at least for the lodging 


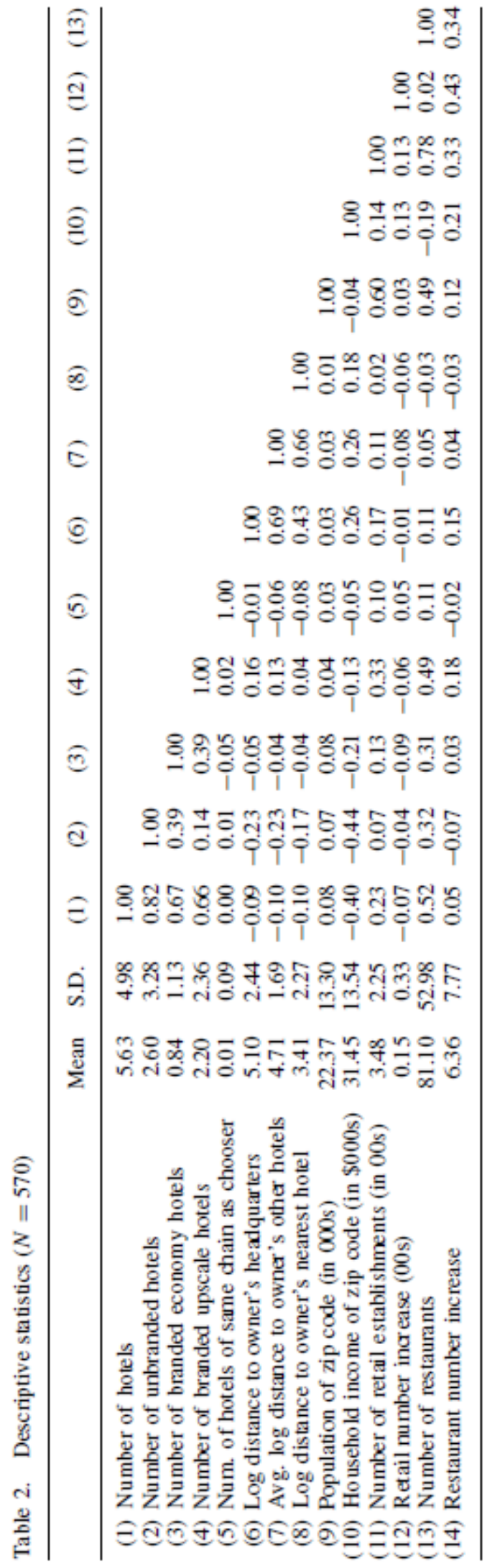


Table 3. Conditional logit results: split by brand affiliations

\begin{tabular}{|c|c|c|c|c|c|c|}
\hline & \multicolumn{3}{|c|}{ Homogeneous markets } & \multicolumn{3}{|c|}{ Heterogeneous markets } \\
\hline & $\begin{array}{l}\text { Branded } \\
\text { upscale } \\
\text { (1) }\end{array}$ & $\begin{array}{l}\text { Branded } \\
\text { economy } \\
\text { (2) }\end{array}$ & $\begin{array}{l}\text { Unbranded } \\
\text { (3) }\end{array}$ & $\begin{array}{l}\text { Branded } \\
\text { upscale } \\
\text { (4) }\end{array}$ & $\begin{array}{l}\text { Branded } \\
\text { economy } \\
\text { (5) }\end{array}$ & $\begin{array}{l}\text { Unbranded } \\
\text { (6) }\end{array}$ \\
\hline Number of hotels & $\begin{array}{c}0.02 \\
(0.01)\end{array}$ & $\begin{array}{l}0.04^{\dagger} \\
(0.02)\end{array}$ & $\begin{array}{l}0.07^{* *} \\
(0.02)\end{array}$ & & & \\
\hline Number of unbranded hotels & & & & $\begin{array}{c}-0.03 \\
(0.03)\end{array}$ & $\begin{array}{c}0.01 \\
(0.03)\end{array}$ & $\begin{array}{c}0.04 \\
(0.04)\end{array}$ \\
\hline $\begin{array}{l}\text { Number of branded } \\
\text { economy hotels }\end{array}$ & & & & $\begin{array}{r}-0.15^{*} \\
(0.06)\end{array}$ & $\begin{array}{c}-0.04 \\
(0.09)\end{array}$ & $\begin{array}{c}-0.08 \\
(0.09)\end{array}$ \\
\hline $\begin{array}{l}\text { Number of branded upscale } \\
\text { hotels }\end{array}$ & & & & $\begin{array}{l}0.20^{4 *} \\
(0.03)\end{array}$ & $\begin{array}{l}0.13^{* *} \\
(0.04)\end{array}$ & $\begin{array}{l}0.22^{*} \\
(0.05)\end{array}$ \\
\hline $\begin{array}{l}\text { Num. of hotels of same } \\
\text { chain as chooser }\end{array}$ & $\begin{array}{r}-1.35^{*} \\
(0.59)\end{array}$ & $\begin{array}{r}-1.31^{\dagger} \\
(0.75)\end{array}$ & & $\begin{array}{l}-1.5^{*} \\
(0.59)\end{array}$ & $\begin{array}{l}-1.3^{*} \\
(0.74)\end{array}$ & \\
\hline $\begin{array}{l}\text { Log distance to owner's } \\
\text { headquarters }\end{array}$ & $\begin{array}{c}-0.66^{*} \\
(0.06)\end{array}$ & $\begin{array}{l}-0.70^{*} \\
(0.08)\end{array}$ & $\begin{array}{l}-1.0^{*} \\
(0.11)\end{array}$ & $\begin{array}{c}-0.67^{*} \\
(0.06)\end{array}$ & $\begin{array}{c}-0.69^{* 4} \\
(0.08)\end{array}$ & $\begin{array}{l}-1.0^{* k} \\
(0.11)\end{array}$ \\
\hline $\begin{array}{l}\text { Avg. log dist. to owner's } \\
\text { other hotels }\end{array}$ & $\begin{array}{c}-0.13 \\
(0.09)\end{array}$ & $\begin{array}{c}-0.13 \\
(0.16)\end{array}$ & $\begin{array}{c}0.11 \\
(0.17)\end{array}$ & $\begin{array}{c}-0.15 \\
(0.09)\end{array}$ & $\begin{array}{c}-0.14 \\
(0.16)\end{array}$ & $\begin{array}{c}0.09 \\
(0.17)\end{array}$ \\
\hline $\begin{array}{l}\text { Log distance to owner's } \\
\text { nearest hotel }\end{array}$ & $\begin{array}{c}-0.38^{4} \\
(0.06)\end{array}$ & $\begin{array}{c}-0.41^{*} \\
(0.12)\end{array}$ & $\begin{array}{r}-0.33^{*} \\
(0.14)\end{array}$ & $\begin{array}{c}-0.34^{4 *} \\
(0.06)\end{array}$ & $\begin{array}{c}-0.42^{* *} \\
(0.12)\end{array}$ & $\begin{array}{r}-0.30^{4} \\
(0.14)\end{array}$ \\
\hline $\begin{array}{l}\text { Population of zip code } \\
\text { (1990) }\end{array}$ & $\begin{array}{r}-1.27^{*} \\
(0.58)\end{array}$ & $\begin{array}{c}0.46 \\
(0.79)\end{array}$ & $\begin{array}{r}-0.68 \\
(0.95)\end{array}$ & $\begin{array}{l}-0.26 \\
(0.57)\end{array}$ & $\begin{array}{c}0.89 \\
(0.78)\end{array}$ & $\begin{array}{c}0.04 \\
(0.94)\end{array}$ \\
\hline $\begin{array}{l}\text { Household income of zip } \\
\text { code (1990) }\end{array}$ & $\begin{array}{c}0.01 \\
(0.01)\end{array}$ & $\begin{array}{c}0.02^{* *} \\
(0.01)\end{array}$ & $\begin{array}{c}0.01 \\
(0.01)\end{array}$ & $\begin{array}{c}0.00 \\
(0.01)\end{array}$ & $\begin{array}{r}0.02^{*} \\
(0.01)\end{array}$ & $\begin{array}{c}0.01 \\
(0.01)\end{array}$ \\
\hline $\begin{array}{l}\text { Number of retail } \\
\text { establishments }\end{array}$ & $\begin{array}{c}0.02 \\
(0.05)\end{array}$ & $\begin{array}{c}-0.04 \\
(0.07)\end{array}$ & $\begin{array}{c}-0.11 \\
(0.09)\end{array}$ & $\begin{array}{c}-0.02 \\
(0.05)\end{array}$ & $\begin{array}{r}-0.06 \\
(0.07)\end{array}$ & $\begin{array}{r}-0.14^{\dagger} \\
(0.08)\end{array}$ \\
\hline $\begin{array}{l}\text { Retail number increase } \\
\text { (entries-exits) }\end{array}$ & $\begin{array}{l}0.27 \\
(0.20)\end{array}$ & $\begin{array}{c}-0.44 \\
(0.31)\end{array}$ & $\begin{array}{c}-0.24 \\
(0.40)\end{array}$ & $\begin{array}{r}0.42^{*} \\
(0.20)\end{array}$ & $\begin{array}{c}-0.38 \\
(0.31)\end{array}$ & $\begin{array}{c}-0.14 \\
(0.40)\end{array}$ \\
\hline Number of restaurants & $\begin{array}{r}0.00^{4} \\
(0.00)\end{array}$ & $\begin{array}{c}0.00 \\
(0.00)\end{array}$ & $\begin{array}{c}0.01 \\
(0.00)\end{array}$ & $\begin{array}{c}0.00 \\
(0.00)\end{array}$ & $\begin{array}{c}0.00 \\
(0.00)\end{array}$ & $\begin{array}{c}0.00 \\
(0.00)\end{array}$ \\
\hline $\begin{array}{l}\text { Restaurant number increase } \\
\text { (entries-exits) }\end{array}$ & $\begin{array}{c}0.03^{* *} \\
(0.01)\end{array}$ & $\begin{array}{r}0.03^{*} \\
(0.01)\end{array}$ & $\begin{array}{c}0.00 \\
(0.02)\end{array}$ & $\begin{array}{c}0.03^{*} \\
(0.01)\end{array}$ & $\begin{array}{r}0.03^{*} \\
(0.01)\end{array}$ & $\begin{array}{c}0.00 \\
(0.02)\end{array}$ \\
\hline $\begin{array}{l}\text { Total observations } \\
\chi^{2} \\
\text { Pseudo } R^{2}\end{array}$ & $\begin{array}{l}296 \\
413.3 \\
0.12\end{array}$ & $\begin{array}{l}161 \\
274.4 \\
0.14\end{array}$ & $\begin{array}{l}113 \\
300.8 \\
024\end{array}$ & $\begin{array}{l}296 \\
453.7 \\
0.13\end{array}$ & $\begin{array}{l}161 \\
280.3 \\
0.15\end{array}$ & $\begin{array}{l}113 \\
312.7\end{array}$ \\
\hline
\end{tabular}

industry, spillovers are a more important driver of agglomeration than is the mere heterogeneity of firms in a market.

These results do provide considerable support for Hypothesis $3 \mathrm{~b}$, which states that the lowresource firms should be relatively more attracted to markets with high-resource firm counts. In column 5 , the insignificant coefficient associated with branded economy hotel counts is marginally significantly smaller ( $\mathrm{f} 2=2.8, \mathrm{p}<0.1$ ) than the significant coefficient associated with high-resource hotel counts, while the insignificant coefficient associated with unbranded hotel counts is significantly smaller ( $\mathrm{f} 2=$ $5.2, p<0.05)$. Further, in column 6 , insignificant coefficients associated with branded economy hotel counts and unbranded counts are strongly significantly smaller ( $f 2=6.5, p<0.01 ; f 2=6.5, p<0.01$ ) than the significant coefficient associated with high- resource hotel counts.

Finally, we point out that some of our control variables generate interesting results. The negative and significant coefficients of the 'Log Distance to Owner's Headquarters' and the 'Log Distance to Owner's Nearest Hotel' variables are consistent with previous literature (Baum et al., 2000; Kalnins and Lafontaine, 2004). These results imply that owners are not likely to venture far outside the area of their headquarters and their existing hotels to own new units. Further, branded upscale hotels are particularly likely to enter high-growth markets - those markets with high growth rates of retail 
establishments and restaurants. It is interesting to note that while the low-resource hotels do follow their high-resource counterparts, they do not follow the lead of entering growth markets absent those upscale hotels.

\section{ROBUSTNESS TESTS}

In addition to the regressions presented above, we conducted several robustness tests. Most importantly, we estimated regressions with hotel size, rather than brand affiliations, as the proxy for possession of resources. In this case, our resource-seeking logic implies that large hotels possess resources that may spill over to proximate small hotels. Using thresholds of 100 rooms and 110 rooms to distinguish large from small, we found significant results. Large hotels strongly avoided areas with many small hotels, while large and small hotels were attracted to areas with large hotels. Thus, our findings are robust beyond one particular proxy for resources.

Second, while we included many control variables to capture a market's attractiveness, some dimensions of demand related to area-specific benefits may be unobservable to researchers. Therefore, we followed Chung and Kalnins (2001) by including dummy variables for each county in regressions otherwise identical to those in Table 3. These dummies eliminate the possibility that significance of high hotel count variables is really being driven by the relative attractiveness of a county, such as the presence of a major tourist attraction.

Third, we investigated the effect of different choice set sizes. The results in Table 3 included all 378 viable markets in Texas as possible choices. With a two-strata approach (see Ben-Akiva and Lerman, 1985: Ch. 9) that included as few as 14 zip codes in the vicinities of the choosing firm's headquarters and the site actually chosen for a new hotel, the results remain at the same levels of significance to those presented in Table 3. This robustness is consistent with Parsons and Hauber's (1998) study that found, also in a geographical setting, that adding many distant alternatives has negligible effects on conditional logit estimation results.

Other robustness tests included recalculating all time-varying variables 3 and 4 years before a hotel's in-business date, rather than 2 years. Further, we changed the AAA stars value at which to split between an upscale and branded economy hotel. We ran regressions with Ramada treated as an upscale brand, as well as regressions with Comfort Inn treated as an economy brand. No results from these tests differed in significance from those presented.

\section{DISCUSSION AND CONCLUSION}

In this paper, we hypothesized that firms often prefer to enter markets with many existing firms because they seek resources that spill over from those incumbents. Combining Fischer and Harrington's (1996) theory of demand-heightening agglomeration with the logic of resource heterogeneity and the potential of spillovers (e.g., Shaver and Flyer, 2000), we argued that heterogeneous resources of both the entering firms and the markets that they enter play a role in location choices. Previous work only considered firm heterogeneity. Shaver and Flyer (2000), for example, showed that high-resource firms avoided agglomeration opportunities, while low-resource firms sought them out. We too found that high-resource firms avoid markets with high counts of incumbent firms, but only when those incumbents were primarily low-resource firms. When a market included high counts of high-resource firms, we found that the market attracted high-resource entrants. Our results that low-resource entrants collocate with others also refined Shaver and Flyer's findings by showing that low-resource 
firms are significantly more likely to collocate with high-resource firms than with others like themselves who lack resources.

We also discussed five alternative processes, summarized above in Table 1, and compared their implications with those of resource-seeking agglomeration. Our results are most consistent with the process of resource-seeking agglomeration for at least three reasons. First, our finding of attraction of upscale hotels to markets with high counts of upscale hotels is inconsistent with a mutualistic process (e.g., Ingram and Baum, 1997; Chung and Kalnins, 2001) and a process of differentiated competition without any agglomeration effects (e.g., Mazzeo, 2002). Second, the finding that economy and unbranded hotels locate in areas with high counts of upscale hotels is inconsistent with processes driven by a quality-contrast effect as well as market segmentation. This finding is consistent with research in marketing that has consistently found firms are unable to benefit by contrasting themselves with lowerquality competitors (e.g., Voss et al., 1998). Third, the result that upscale hotels avoid areas with economy hotels contradicts the possibility that we are merely observing effects of area-specific benefits, that is, certain markets being more attractive than others because they are the home of particular attractions. If that were the case, we should observe all new hotels preferring markets with high counts of all types. Finally, the fact that our sample consisted solely of existing hotel operators expanding into new markets allows us to eliminate the possibility of another process not considered earlier: that agglomeration has resulted from the founding of new firms by employees departing from proximate existing firms (e.g., Sorensen and Audia, 2000).

Overall, our findings show a general trend towards clustering of firms. However, the fact that the high-resource firms avoid their low-resource counterparts suggests an interesting intermediary dynamic. High-resource firms will collocate with others like themselves. But this collocation will also attract low-resource firms, which in turn makes that market less attractive for further high- resource entrants. These firms, then, will prefer to locate by themselves in order to avoid the existing lowresource firms. By doing so, however, they will attract other firms of both types who will disturb their solitude, and the process will begin again in a new market founded by a high- resource firm wishing to avoid the spillovers of its resources.

Clear practitioner implications emerge from our findings-notably for owners and managers of high-resource firms. High-resource firms need to reduce spillovers that their resource stocks create and develop mechanisms to appropriate some of these spillovers' proceeds. Despite avoiding locations where low-resource firms already reside, the high-resource firm may often find low-resource firms appearing afterwards, making the benefits of one's own demand-heightening resources particularly hard to protect. Since moving away is rarely an option, the owners of high-resource firms may find it beneficial to control nearby low-resource firms. For example, Marriott hotels will be flanked by Courtyard by Marriott and Fairfield Inns. The agglomeration benefits that the flagship Marriott hotel generates are captured by the collocated economy brands that Marriott owns. Further, Marriott's 'economy' brands are still high enough in quality that they do not diminish the value of the Marriott flagship hotel in the vicinity. Also, in some retail settings such as shopping malls, large nationally known 'anchor' stores pay lower rent in recognition of the demand-heightening resources they provide others (Pashigian and Gould, 1998). High-resource firms might also obtain tax incentives from the locations that they are considering. Local governments give tax breaks to attract high- resource firms not only because of the employment that the firms themselves are expected to generate, but also because of the expectation that other firms will collocate. These collocating firms will also be generating employment and paying taxes (see, for example, Calantone and Loof, 1987). These examples highlight that to maintain and benefit from competitive advantage, firm managers must do more than create resources. 
When in a resource-seeking environment, they must focus on strategies to appropriate returns from the spillovers of their resource stocks.

\section{REFERENCES}

Ahuja G. 2000. The duality of collaboration: Inducements and opportunities in the formation of interfirm linkages. Strategic Management Journal 21(3): 317-343.

Almeida P, Kogut B. 1999. Localization of knowledge and the mobility of engineers in regional networks. Management Science 45: 905-917.

Barnett W, Carroll G. 1987. Competition and mutualism among early telephone companies. Administrative Science Quarterly 32: 400-421.

Barney J, Arikan A. 2001. The resource-based view: origins and implications. In The Blackwell Handbook of Strategic Management, Hitt M, Freeman R, Harrison J (eds). Blackwell: Malden, MA; 124-188.

Baum J, Li S, Usher J. 2000. Making the next move: how experiential and vicarious learning shape the location of chains' acquisitions. Administrative Science Quarterly 45: 766-801.

Ben-Akiva M, Lerman S. 1985. Discrete Choice Analysis . MIT Press: Cambridge, MA.

Brandenburger A, NalebuffB. 1996. Co-opetition. Doubleday: New York.

Calantone R, Loof C. 1987. Estimated impact of Toyota on Kentucky. Review and Perspective, College of Business and Economics, University of Kentucky 1: 5-18.

Carlton D. 1983. The location and employment choices of new firms: an econometric model with discrete and continuous variables. Review of Economics and Statistics 65: 440-449.

Caves R, Murphy W. 1976. Franchising: firms, markets, and intangible assets. Southern Economic Journal 42: 572-586.

Chung W, Kalnins A. 2001. Agglomeration effects and performance: a test of the Texas lodging industry. Strategic Management Journal 22(10): 969-988.

Cobb-Walgren C, Ruble C, Donthu N. 1995. Brand equity, brand preference, and purchase intent. Journal of Advertising 24: 25-40.

Conlin M. 2003. The effect of franchising on competition: an empirical analysis (mimeo). Economics Department, Syracuse University.

Dierickx I, Cool K. 1989. Asset stock accumulation and sustainability of competitive advantage. Management Science 35: 1504-1511.

Dyer J, Singh H. 1998. The relational view: cooperative strategies and sources of interorganizational competitive advantage. Academy of Management Review 23: 660-679.

Fischer J, Harrington J. 1996. Product variety and firm agglomeration. RAND Journal of Economics 27: 281-309.

Head K, Ries J, Swenson D. 1995. Agglomeration benefits and location choice: evidence from Japanese manufacturing investments. Journal of International Economics 38: 223-247.

Hotelling H. 1929. Stability in competition. Economic Journal 39: 41-57. 
Ingram P. 1996. Organizational form as a solution to the problem of credible commitment: the evolution of naming strategies among U.S. hotel chains, 1896-1980. Strategic Management Journal, Summer Special Issue 17: 85-98.

Ingram P, Baum J. 1997. Chain affiliation and the failure of Manhattan hotels, 1898-1980. Administrative Science Quarterly 41: 68-102.

Jaffe A, Trajtenberg M, Henderson R. 1993. Geographic localization of knowledge spillovers as evidenced by patent citations. Quarterly Journal of Economics 108: 578-598.

Kalnins A, Lafontaine F. 2004. Multi-unit ownership in franchising: evidence from the fast-food industry in Texas. RAND Journal of Economics, forthcoming.

Khanna T, Ganot I. 1995. Choice Hotels International 1995. Harvard Case Study \#9-795-165. Harvard Business School Press: Cambridge, MA.

Marshall A. 1920. Principles of Economics. Macmillan: London.

Mazzeo M. 2002. Product choice and oligopoly market structure. RAND Journal of Economics 33: 1 -22.

McFadden D. 1974. Conditional logit analysis of qualitative choice behavior. In Frontiers in

Econometrics, Zarembka P (ed). Academic Press: New York; 105 - 142.

Milgrom P, Roberts J. 1986. Price and advertising signals of product quality. Journal of Political Economy 94: 796-821.

Parsons G, Hauber A. 1998. Spatial boundaries and choice-set definition in a random utility model of recreation demand. Land Economics 74: 32-48.

Pashigian P, Gould E. 1998. Internalizing externalities: the pricing of space in shopping malls. Journal of Law and Economics 41: 115-142.

Rao A, Ruekert R. 1994. Brand alliances as signals of product quality. Sloan Management Review 36(1): 87-97.

Shaver J, Flyer F. 2000. Agglomeration economies, firm heterogeneity, and foreign direct investment in the United States. Strategic Management Journal 21(12): 1175-1193.

Sorensen O, Audia P. 2000. The social structure of entrepreneurial activity: geographic concentration of footwear production in the United States 1940-1989. American Journal of Sociology 106: 224-262.

Tirole J. 1988. The Theory of Industrial Organization. MIT Press: Cambridge, MA.

Voss G, Parasuraman A, Grewal D. 1998. The roles of price, performance, and expectations in determining satisfaction in service exchanges. Journal of Marketing 62: 46-61.

Wernerfelt B. 1988. Umbrella branding as a signal of new product quality: an example of signaling by posting a bond. RAND Journal of Economics 19: 458-466. 